\title{
PENGARUH PERUBAHAN DIVIDEN TERHADAP PROFITABILITAS PERUSAHAAN PADA MASA YANG AKAN DATANG (FUTURE PROFITABILITY)
}

\author{
Agus Prasetyanta \\ Fakultas Ekonomi Universitas Kristen Immanuel Yogyakarta \\ agusprasetyanta@yahoo.com, aprasetyanta@gmail.com
}

\begin{abstract}
The research investigates the incremental information content of dividend changes about future profitability. We regress three of measurement of earnings (earnings level, earnings changes and abnormal earnings) to dividend changes and a number of control variables. By using 87 samples (420 firm years) of firm at Jakarta Stock Exchange over 1997-2003, We find that dividend changes provide information about the earnings insubsequent years, incremental to market and accounting data. The paper also documents that dividend changes are positively related to earnings changes for merely four year ahead. In detail examining, We find that dividend increase convey must new information about earnings changes and abnormal earnings for three year ahead than dividend decrease.
\end{abstract}

Keywords: incremental information content, dividend changes, profitability

\section{PENDAHULUAN}

Seorang investor yang rasional melakukan analisis sebelum membuat keputusan untuk berinvestasi. Investor membutuhkan informasi yang akan dijadikan sinyal untuk menilai prospek masa depan perusahaan. Terdapat dua jenis informasi yang merupakan sinyal penting bagi investor untuk menilai prospek masa depan perusahaan, yaitu laba per lembar saham dan dividen per lembar saham (Bukit dan Jogiyanto 2000).

Pengumuman dividen merupakan salah satu informasi yang akan direspon pasar, sebab seringkali dividen sebagai indikator prospek perusahaan dan mempunyai pengaruh terhadap nilai perusahaan. Perusahaan yang menetapkan kebijakan kenaikan pembayaran dividen merupakan sinyal yang baik dan pasar akan merespon positif. Sebaliknya kebijakan perusahaan untuk menurunkan pembayaran dividen merupakan sinyal yang buruk, sehingga pasar akan bereaksi negatif. Miller dan Modigliani memperkenalkan ide bahwa dividen menghasilkan informasi tentang profitabilitas masa depan dan hal ini dapat mempengaruhi harga saham. Mereka menyatakan bahwa investor kemungkinan menginterpretasikan perubahan dividen 
sebagai perubahan pandangan manajemen terhadap prospek profit perusahaan di masa yang akan datang (Wansley, et al., 1991).

Kebijakan dividen merupakan salah satu kebijakan, di samping dua kebijakan yang lain, yaitu keputusan investasi dan keputusan struktur modal. Kebijakan dividen adalah keputusan mengenai apakah laba yang diperoleh perusahaan akan dibagikan kepada pemegang saham sebagai dividen atau akan ditahan dalam bentuk laba ditahan guna pembiayaan investasi pada masa yang akan datang. Setiap perusahaan akan mengumumkan kebijakan dividen kepada publik dan pengumuman dividen merupakan salah satu sarana untuk menginformasikan prestasi prospek perusahaan. Berdasarkan informasi kebijakan dividen, pasar akan bereaksi secara berbeda dalam menafsirkan perusahaan tersebut. Reaksi pasar terhadap pengumuman dividen menunjukkan reaksi pasar mengenai prospek perusahaan pada masa yang akan datang. Peningkatan dividen memberikan sinyal perubahan yang menguntungkan pada harapan manajer dan penurunan dividen menunjukkan pandangan pesimis prospek perusahaan di masa yang akan datang (Aharony dan Swary 1980).

Penelitian tentang dividen telah banyak dilakukan, namun masih menyisakan sejumlah pertanyaan yang belum terjawab atau temuan-temuan yang yang belum konsisten. Kenyataan tersebut memperkuat pernyataan bahwa kebijakan dividen masih merupakan teka-teki (puzzle). Riset mengenai hubungan antara perubahan dividen dengan profitabilitas perusahaan di masa yang akan datang masih menjadi perdebatan. Penelitian yang dilakukan oleh DeAngelo, DeAngelo dan Skiner (1996), Benartzi et al. (1997) belum dapat menunjukkan bukti yang kuat, meskipun pernyataan bahwa perubahan dividen memicu return saham, karena mengandung informasi baru tentang profitabilitas perusahaan di masa yang akan datang telah diyakini sejak awal (Miller dan Modigliani 1961).

Menurut penelitian yang dilakukan oleh Watts (1976), dalam upaya awal untuk mengidentifikasi hubungan antara perubahan dividen dengan prospek perusahaan, memperoleh kesimpulan bahwa observasi mengenai unexpected dividend change tidak bisa disimpulkan sebagai tanda perubahan unexpected earnings di masa yang akan datang, karenanya akan sangat berbeda dari nol.

Sementara penelitian yang dilakukan oleh Denis dan Sarin (1994) berpendapat penjelasan tentang hubungan positif antara pengumuman dividen dan perubahan harga saham. Pertama, adanya teori dividend signaling dimana perubahan dividen mengandung informasi tentang aliran kas yaitu peningkatan (penurunan) dividen mengandung good (bad) news tentang aliran kas perusahaan pada saat ini atau di masa yang akan datang. Kedua, perubahan dividen dapat memberikan informasi mengenai investasi perusahaan di masa yang akan datang (Lang dan Lintzenberger 1989). 
Asquith dan Mullins (1983) memperoleh bukti adanya excess return yang positif dan cukup kuat. Excess return yang positif berhubungan dengan besarnya jumlah dividen awal yang dibayarkan. Sehubungan dengan hal tersebut maka peningkatan dividen yang dibayarkan untuk periode selanjutnya akan memberikan pengaruh positif yang besar pada kemakmuran pemegang saham.

Berdasarkan beberapa penelitian yang telah dilakukan, terdapat dua kelompok peneliti yang bertentangan mengenai pengaruh dividend changes terhadap keuntungan saham (stock return). Penelitian yang menyatakan bahwa dividend changes secara positif mempengaruhi profitabilitas perusahaan antara lain dilakukan oleh: Aharony and Swary (1980), Asquith and Mullins (1983), Kalay and Loewenstein (1985) dan Petit (1972). Kelompok ini mendukung pendapat Miller and Modigliani (1961) yang menyatakan bahwa dividend changes memicu keuntungan saham (stock return), karena dividend change membawa informasi baru mengenai profitabilitas perusahaan pada masa yang akan datang (future profitability).

Kelompok kedua yaitu kelompok yang menyatakan bahwa dividend changes tidak berhubungan dengan profitabilitas perusahaan pada masa yang datang. Kelompok kedua ini antara lain adalah: DeAngelo, DeAngelo and Skiner (1966), Benartzi, Michael and Thaler (BMT 1997). Kedua kelompok peneliti tersebut menghasilkan suatu kesimpulan yang kontradiktif mengenai pengaruh perubahan dividen terhadap keuntungan saham (stock return) yang dapat mencerminkan profitabilitas perusahaan pada masa yang akan datang. Dari kedua kelompok peneliti tersebut ternyata kelompok yang menyatakan bahwa perubahan dividen tidak berpengaruh secara positif terhadap profitabilitas lebih dominan. Oleh karena itu, penelitian ini bertujuan untuk menguji kembali hubungan antara perubahan dividen dan alternatif pengukuran profitabilitas dan juga memberikan bukti yang kuat bahwa perubahan dividen secara positif berhubungan dengan profitabilitas perusahaan yang tercermin dalam perubahan future earnings dan future abnormal earnings.

Untuk meneliti apakah dividend changes mengandung informasi baru mengenai future profitability, maka harus dilakukan estimasi profitabilitas yang diharapkan. Penelitian-penelitian yang pernah dilakukan sebagian besar mengasumsikan bahwa earnings mengikuti arah yang random (random walk) dan profitabilitas yang diharapkan diukur sebagai perubahan realisasi earnings dikurangi dengan estimasi. Sehingga hubungan antara dividend changes dan unexpected earnings hanya dilihat berdasarkan perubahan earnings. Berdasarkan metode tersebut diperoleh hasil, bahwa dividend changes tidak berhubungan secara positif dengan perubahan future earnings. Kemudian dilakukan modifikasi model penelitian dengan menekankan isu yang berhubungan dengan estimasi unexpected earnings yaitu pengukuran error dan mengabaikan variabel korelasi. Dengan model yang baru ini dapat ditunjukkan bahwa dividend changes secara positif berhubungan dengan earnings changes pada setiap dua tahun setelah dividend changes. 
Analisis juga dikembangkan dengan melakukan pengujian kembali hubungan antara perubahan dividen dan tingkat profitabilitas yang akan datang, dengan kontrol profit pada tahun perubahan dividen dan profit yang diharapkan berdasarkan informasi yang tersedia sebelum perubahan dividen. Penelitian ini menggunakan dua alternatif pengukuran profit, yaitu earnings dan abnormal earnings.

Model penelitian ini merupakan pengujian kembali hasil penelitian yang pernah dilakukan mengenai hubungan antara perubahan dividen dengan profitabilitas perusahaan. Sampel data penelitian yang dilakukan oleh Doron Nissim \& Amir Ziv diambil dari data perusahaan di NYSE periode tahun 1963 sampai tahun 1997. Penelitian tersebut bertujuan untuk membuktikan bahwa perubahan dividen secara positif berhubungan dengan perubahan earnings perusahaan. Berdasarkan penelitian tersebut juga dapat dibuktikan bahwa kenaikan dividen secara positif mempengaruhi profitabilitas perusahaan, sedangkan penurunan dividen tidak mempengaruhi secara positif terhadap profitabilitas perusahaan.

Menurut Nissin dan Ziv (2001), profitabilitas diukur dengan alternatif abnormal earning, seperti yang digunakan oleh Benartzi et al. (1997). Menurut peneliti pengukuran ini lebih realistis dalam menghitung abnormal earning, karena mempertimbangkan rata-rata perubahan laba dalam industri sejenis. Seperti diketahui bahwa laba perusahaan tidak hanya dipengaruhi oleh kinerja internal perusahaan, tetapi juga berkovari dengan profitabilitas industrinya. Sedangkan menurut penelitian yang dilakukan oleh Nissin dan Ziv (2001), abnormal earning hanya dihitung berdasarkan pada selisih antara laba aktual dengan laba yang diharapkan dari cost dan tingkat modal ekuitas yang diinvestasikan.

Bukti-bukti empiris tentang reaksi pasar terhadap pengumuman dividen yang berbeda-beda mendorong peneliti untuk melakukan penelitian lanjutan tentang reaksi pasar terhadap pengumuman perubahan dividen di Bursa Efek Jakarta (BEJ). Penelitian-penelitian sebelumnya tentang pengumuman perubahan dividen tersebut (baik pembayaran dividen naik atau turun serta dividend initiations ataupun dividend omissions), belum ada yang mengaitkan dengan tingkat pertumbuhan perusahaan.

Berdasarkan latar belakang masalah tersebut penulis tertarik untuk melakukan penelitian mengenai pengaruh perubahan dividen (dividend changes) terhadap profitabilitas perusahaan pada waktu yang akan datang (future profitability), pada perusahaan yang ada di Indonesia, khususnya bagi perusahaan yang terdaftar di BEJ. Penelitian ini menarik karena selama ini penelitian mengenai pengaruh suatu informasi terhadap harga saham berupa event studies dan masih jarang penelitian di BEJ mengenai pengaruh informasi terhadap profitabilitas perusahaan.

Dalam penelitian ini akan dibahas apakah pengaruh perubahan dividen (dividend changes) secara positif mempengaruhi profitabilitas perusahaan (future profitability), yang tercermin dalam earning, perubahan earning dan abnormal 
earning. Disamping itu dalam penelitian ini juga akan dilihat apakah kenaikan dividen (dividend increase) secara positif mempengaruhi profitabilas perusahaan (future profitability). Tujuan penelitian ini adalah antara lain, untuk menguji apakah ada pengaruh pengumuman perubahan dividen terhadap profitabilitas perusahaan yang terdaftar di BEJ dan untuk memperoleh bukti empiris dengan menggunakan model penelitian Doron, Nissim dan Amir Ziv (2001), mengenai pengaruh perubahan dividen terhadap earning perusahaan pada periode setelah pengumuman.

Melalui pengujian empiris yang telah dilakukan, hasil penelitian ini diharapkan dapat memberikan informasi dan bukti empiris mengenai ada tidaknya kandungan informasi dari perubahan dividen terhadap prospek perusahaan di waktu yang akan datang dan mengetahui bentuk efisiensi pasar di BEJ. Bagi perusahaan, hasil penelitian ini bisa dijadikan pedoman untuk menyusun kebijakan dividen (dividend policy). Sedangkan bagi investor hasil penelitian ini dapat dijadikan pedoman dalam melihat hal apa yang akan terjadi setelah pengumuman perubahan dividen. Dan bagi publik, hasil penelitian ini dapat menjadi sumber informasi bagi calon investor yang tertarik untuk memasuki dunia pasar modal dengan melihat adanya signal dari setiap pengumuman dividen yang dilakukan oleh perusahaan.

\section{LANDASAN TEORI DAN HIPOTESIS}

\section{Teori Kebijakan Deviden}

Kebijakan dividen adalah keputusan apakah laba yang diperoleh perusahaan akan dibagikan kepada pemegang saham sebagai dividen atau akan ditahan dalam bentuk laba ditahan guna pembiayaan investasi di masa yang akan datang. Laba ditahan dapat menjadi sumber dana internal sehingga apabila perusahaan memutuskan tidak membagi dividen maka kesempatan pembentukan dana internal semakin besar. Teori-teori kebijakan dividen menjadi perhatian dengan masih adanya "puzzle" yang akan dicoba dibuktikan oleh para peneliti. Teori-teori kebijakan dividen yang dimaksud adalah teori Modigliani Miller (MM), GordonLinter dan Litzenberger-Ramaswamy (Brigham and Gapenski 1996).

Modigliani dan Miller (1961) berpendapat bahwa kebijakan dividen tidak mempunyai pengaruh pada harga saham perusahaan atau biaya modalnya. Modigliani dan Miller menyatakan bahwa kebijakan dividen adalah tidak relevan, selanjutnya nilai perusahaan ditentukan oleh earning power dari asset perusahaan. Sementara itu keputusan apakah laba yang diperoleh akan dibagikan dalam bentuk dividen atau akan ditahan tidak mempengaruhi perusahaan. Menurut Modigliani dan Miller, apabila perusahaan membagikan dividen kepada pemegang saham maka perusahaan harus mengeluarkan saham baru sebagai pengganti sejumlah pembayaran dividen tersebut. Dengan demikian kenaikan pendapatan dari pembayaran dividen akan diimbangi dengan penurunan harga saham sebagai akibat penjualan saham baru (Sartono 1996). Dengan demikian kebijakan membagi laba atau menahan laba tidak 
berpengaruh pada kemakmuran para pemegang saham.

Menurut Bird-in-the Hand Theory yang disampaikan oleh Gordon dan Lintner, beranggapan bahwa investor memandang bahwa satu burung ditangan lebih berharga daripada seribu burung di udara. Investor lebih merasa aman memperoleh pendapatan berupa pembayaran dividen dari pada menunggu capital gain yang diharapkan lebih besar risikonya dibanding dengan dividend yield. Gordon dan Lintner beranggapan bahwa kemungkinan mendapatkan capital gain lebih besar risikonya dibandingkan dengan pembayaran dividen yang sudah pasti. Sehingga investor akan meminta tingkat keuntungan yang lebih tinggi untuk setiap pengurangan dividend yield. Litzenberger dan Ramaswamy berpendapat bahwa karena dividen cenderung dikenakan pajak yang lebih tinggi daripada capital gain, maka investor akan meminta tingkat keuntungan yang lebih tinggi untuk saham dengan dividend yield yang tinggi. Mereka juga menyarankan perusahaan lebih baik menentukan dividend payout ratio yang rendah atau bahkan tidak membagikan dividen sama sekali untuk meminimumkan biaya modal dan memaksimumkan nilai perusahaan. Pendapat ini bertentangan dengan pendapat Gordon dan Lintner.

Berdasarkan ketiga teori tersebut dapat disimpulkan: (1) Modigliani-Miller berpendapat bahwa kebijakan dividen tidak berpengaruh terhadap nilai perusahaan ataupun biaya modal. Sehingga dapat dikatakan bahwa kebijakan dividen adalah tidak relevan; (2) Gordon dan Lintner berpendapat bahwa dividen lebih kecil risikonya dibandingkan dengan capital gain, sehingga para pemegang saham memilih pembagian dividen dan (3) Litzenberger dan Ramaswamy berpendapat bahwa sebaiknya perusahaan tidak membagikan dividen karena dividen cenderung dikenai pajak yang lebih tinggi daripada capital gain.

\section{Hasil Penelitian Terdahulu}

Hasil penelitian Healy dan Palepu (1988), Michaely et al. (1995) menunjukkan bahwa kenaikan dividen sering diikuti dengan kenaikan harga saham. Menurut teori signalling, pasar menganggap peningkatan dividen sebagai sinyal peningkatan kinerja perusahaan saat ini maupun prospeknya di masa depan. Peningkatan dividen dianggap sebagai sinyal keuntungan perusahaan. Perusahaan meningkatkan pembayaran dividen kalau arus kas yang ada di perusahaan mencukupi.

Miller dan Modigliani (1961) memperkenalkan ide bahwa dividen menghasilkan informasi tentang profitabilitas masa depan dan hal ini dapat mempengaruhi harga saham. Mereka menyatakan bahwa investor kemungkinan menginterpretasikan perubahan dividen sebagai perubahan pandangan manajemen terhadap prospek profit perusahaan di masa yang akan datang (Wansley et al., 1991)

Manajemen tidak akan mengubah dividen, kecuali mereka mempunyai alasan untuk mengharapkan perubahan yang signifikan pada prospek perusahaan di masa yang akan datang. Oleh karena itu, peningkatan dividen memberikan sinyal 
perubahan yang menguntungkan pada harapan manajer dan penurunan dividen menunjukkan pandangan pesimis prospek perusahaan di masa yang akan datang (Aharoy dan Swary 1980).

Watts (1976) pada upaya awalnya dalam mengidentifikasi hubungan tersebut, memperoleh kesimpulan bahwa "observasi mengenai unexpected dividend change tidak bisa disimpulkan sebagai tanda bahwa ada perubahan unexpectecd earning di masa yang akan datang, karenanya akan sangat berbeda dari nol.”

Asquith dan Mullins (1983) memproleh bukti adanya excess return yang positif dan cukup kuat. Excess return yang positif berhubungan dengan besarnya jumlah dividen awal dibayarkan. Sehubungan dengan hal tersebut maka peningkatan dividen yang dibayarkan untuk periode selanjutnya akan memberikan pengaruh positif yang besar pada kemakmuran pemegang saham. Selanjutnya Asquith dan Mullins mengemukakan adanya pengaruh yang positif dari kebijakan dividen disebabkan oleh adanya mekanisma yang dapat mengkomunikasikan informasi manajemen mengenai kinerja perusahaan saat ini dan masa yang akan datang. Hal ini sesuai dengan bukti empiris pada penelitian sebelumnya mengenai kebijakan dividen yang dikemukakan oleh Litner (1956), Brttain (1966), Fama dan Babiak (1968), Ross (1977) dan Battcharya $(1979,1980)$ mengenai model asimetri informasi dimana dividen membawa sinyal mengenai kinerja perusahaan saat ini dan prospeknya pada masa datang. Bukti yang sama juga dikemukakan oleh Miller dan Rock (1982) yang menyatakan bahwa adanya asimetri informasi antara investor dan manajemen karena perubahan dividen akan berdampak pada reaksi harga pasar saham.

Terdapat hubungan antara dividend change dengan future earning changes (Benartzi et al., 1997), dimana dividend changes merupakan tingkat perubahan dividen pada tahun ke 0 dan earning changes pada tahun ke 0 , ke 1 dan ke 2 diukur dengan nilai pasar saham pada dividend changes awal tahun. Denis dan Sarin (1994) berpendapat bahwa penjelasan hubungan positif antara pengumuman dividen dan perubahan harga saham, yaitu: (1) adanya teori dividend signaling dimana perubahan dividen mengandung informasi tentang aliran kas perusahaan pada saat ini dan di masa yang akan datang, (2) perubahan dividen dapat memberikan informasi mengenai investasi perusahaan di masa yang akan datang (Lang dan Lintzenberger 1989).

Penelitian yang dilakukan oleh Benartzi et al. (1997) mengenai hubungan antara perubahan dividen dan perubahan earnings, dengan menguji korelasi antara tingkat perubahan dividen per lembar saham pada tahun nol, pertama dan kedua dengan skala nilai buku saham pada awal tahun perubahan dividen. Penelitian tersebut mengasumsikan bahwa earnings mengikuti pola random walk, sehingga perubahan earnings merupakan ukuran unexpected profitability. Penelitian tersebut dilakukan dengan menggunakan analisis katagorikal dan regresi, 
menyimpulkan bahwa kenaikan atau penurunan dividen pada tahun berjalan akan lebih tinggi atau lebih rendah dibandingkan dengan earnings pada tahun sebelumnya. Penelitian tersebut tidak menemukan hubungan yang signifikan antara perubahan dividen dengan perubahan earnings. Hubungan yang tidak signifikan antara perubahan dividen dengan perubahan earnings terjadi karena adanya kesalahan pengukuran pada variabel dependen, sehingga dilakukan perubahan pengukuran perubahan earnings dengan nilai buku saham bukan dengan nilai pasar saham. Ukuran profitabilitas dapat dilihat dari earnings pada tahun berjalan dikurangi dengan earnings pada tahun sebelumnya.

Berdasarkan data-data tersebut, maka hipotesis yang akan diuji adalah:

H1: Informasi perubahan dividen mengandung informasi inkremental tentang profitabilitas perusahaan di masa yang akan datang.

H2: Informasi perubahan dividen berkorelasi positif dengan profitabilitas perusahaan di masa yang akan datang.

Perusahaan dengan menaikkan atau menurunkan dividen biasanya mempunyai rasio current earning to price yang tinggi atau rendah, sehingga hal ini menimbulkan error (Benartzi et al., 1997). Oleh karena itu, earning changes dikontrol dengan book value of common equity. Menurut penelitian Freeman, Ohlson dan Penman (1982) menunjukkan bahwa predictor penting dari earning changes adalah ratio earning dengan book value equity (ROE). ROE yang tinggi mengimplikasikan penurunan expected earnings (Fama dan French 2000). Denis dan Sarin (1994) berpendapat bahwa penjelasan hubungan positif antara pengumuman dividen dan perubahan saham, yaitu: (1) adanya teori dividend signal dimana perubahan mengandung informasi tentang aliran kas perusahaan pada saat ini atau dimasa akan datang, (2) perubahan dividen dapat memberikan informasi mengenai investasi perusahaan dimasa yang akan datang (Lang dan Lintzberger 1989).

Menurut penelitian DeAngelo dan DeAngelo (1990) dan Beartzi et al. (1997), hubungan antara dividend changes dan earning changes tidak simetris untuk kenaikan dan penurunan dividen, sehingga perlu ditambahkan dummy variable $(D P C / D N C)$, dimana $D P C=1$ untuk dividend changes atau decrease dan decrease dan $D P C=0$ untuk yang lain. Sesuai dengan prinsip akuntansi yaitu prinsip conservatism, hanya dividend increase secara positif mempengaruhi profitability, karena dividend increase merupakan good news sedangkan dividend decrease merupakan bad news belum diakui sebagai pendapatan. Untuk mengukur profitabilitas perusahaan dapat menggunakan abnormal earnings. Sehingga hipotesis kedua yang akan diuji dalam penelitian ini adalah sebagai berikut.

H3: Kandungan informasi incremental perubahan dividen meningkat dan menurun tentang profitabilitas perusahaan di masa yang akan datang adalah berbeda. 


\section{METODA PENELITIAN}

\section{Populasi dan Sampel}

Populasi dari penelitian ini adalah seluruh perusahaan yang terdaftar di Bursa Efek Jakarta (BEJ), yaitu dari Indonesian Capital Market Directory (ICMD). Data yang dibutuhkan di antaranya terdiri dari harga saham dan pengumuman dividen tahun 1997 sampai dengan tahun 2003. Metoda pengumpulan sampel menggunakan purposive sampling. Kriteria sampel yang akan diteliti adalah (1) sampel adalah semua perusahaan yang terdaftar di BEJ kecuali perusahaan bidang keuangan (financial service), supaya data tidak terlalu banyak, (2) perusahaan memiliki kebijakan dividen dan paling tidak telah mengumumkan pembayaran dividen dua tahun berturut-turut dalam periode 1997-2003, sehingga dapat diperoleh minimal satu tahun perubahan dividen, (3) sampel hanya melibatkan perubahan dividen yang tidak terkontaminasi dengan distribusi abnormal lainnya (other abnormal distribution), dalam hal ini yang dimaksud adalah stock split dan stock dividend (Aharony \& Dotan 1994, Doron Nissim \& Amir Ziv 2001), (4) sampel telah menerbitkan laporan laba-rugi dalam periode 1997-2003.

Data-data yang digunakan dalam penelitian ini adalah data sekunder dan diolah secara panel. Data-data tersebut masing-masing adalah (1) laporan laba-rugi dalam periode 1997-2003, yang diperoleh dari ICMD yang diterbitkan oleh Institute for Economic and Financial Research, (2) data pengumuman dividen dalam periode 1998-2003 yang diperoleh dari Fact Book yang diterbitkan oleh Jakarta Stock Exchange dan Pusat Data Pasar Modal (PDPM) PPA FE UGM, (3) data lainnya yang menjadi variabel penelitian diperoleh dari ICMD dan Jakarta Stock Exchange Statistic.

\section{PEMILIHAN DAN PENGUKURAN VARIABEL}

\section{Variabel Dependen}

Variabel dependen dalam penelitian ini adalah laba tahunan perusahaan. Pengukuran laba yang digunakan dalam penelitian ini adalah: (1) tingkat laba (earning); (2) perubahan laba (earning change) dan (3) laba tidak normal (abnormal earning). Ukuran profitabilitas dengan menggunakan earning dan earning change mengacu pada penelitian yang dilakukan oleh Nissim dan Ziv (2001), sedangkan pengukuran profitabilitas dengan menggunakan abnormal earning mengacu pada Benartzi et al. (1997).

Variabel tingkat laba (earning) dihitung dari laba bersih tahunan sebelum item luar biasa dan operasi yang tidak berkelanjutan pada tahun $t$ dibagi dengan nilai buku ekuitas (BVE). Sedangkan perubahan laba $(\Delta E)$, dihitung dengan persamaan:

$\Delta E_{t}=\left(E_{t}-E_{t-1}\right) / B V E_{t-1}$ 


\section{Keterangan}

$\boldsymbol{E}_{\boldsymbol{t}} \quad=$ Laba bersih tahunan sebelum item luar biasa dan operasi yang tidak berkelanjutan pada tahun $\boldsymbol{t}$ dan $\boldsymbol{t}-\boldsymbol{1}$.

BVEt-1 = Nilai buku ekuitas pada waktut-1. Deflasi perubahan laba dengan nilai buku ekuitas dimaksudkan untuk meminimalkan pengaruh size perusahaan yang menjadi sampel.

Laba tidak normal (abnormal earning) merupakan selisih antara laba actual perusahaan dengan rata-rata laba perusahaan yang membayar dividen tetap pada waktu $\boldsymbol{t}_{\boldsymbol{0}}$ pada industri yang sama. Perhitungan ini didasarkan pada asumsi bahwa laba perusahaan mengikuti pola random walk dan oleh karena itu, salah satu penyesuaian yang dapat dilakukan adalah membandingkan perusahaan yang mengubah dividennya dengan yang tidak mengubah dividennya. Penyesuaian ini berarti bahwa kita dapat mengasumsikan laba ekspektasian (expected earnings) sama dengan laba $t-1$ ditambah dengan rata-rata perubahan laba perusahaan yang membayar dividen tetap pada waktu $\boldsymbol{t}_{\boldsymbol{0}}$ dalam industri yang sama. Dengan dasar itu, maka laba tidak normal (abnormal earnings=unexpected earnings) dapat dihitung dengan rumus sebagai berikut (Benartzi et al., 1997):

$A E t=\Delta E t-{ }^{1} / j \Sigma \Delta E 0$

Dimana $J=1 \ldots ., j$ adalah semua perusahaan yang membayar dividen tetap pada waktu $t 0$ dalam industri yang sama.

Dalam penelitian ini laba tidak normal $(A E)$ dihitung berdasarkan penelitian Benartzi et al. (1997), tidak menurut Nissim dan Ziv (2001). Hal ini dilakukan karena menurut Benartzi et al. perhitungan dilakukan dengan melibatkan rata-rata perubahan laba dalam industri yang sama, dimana diketahui bahwa profitabilitas perusahaan berkovari dengan profitabilitas industrinya, sedangkan menurut Nissim dan Ziv, perhitungan laba tidak normal berdasarkan kos dan tingkat ekuitas yang diinvestasikan.

\section{Variabel Independen}

Perubahan dividen merupakan variabel penjelas utama dalam penelitian ini. Perubahan dividen dihitung dengan menggunakan persamaan berikut ini.

$\Delta D I V_{i, 0}=D I V_{i, 0}-D I V i,-1$

Keterangan:

Perusahaan $i$ yang membayar dividen pada waktu $t 0$.

Perusahaan $i$ yang membayar dividen pada waktu $t-1$.

Perubahan dividen dapat dihitung dengan dua perubahan total atau dengan tingkat perubahan dividen, yaitu pembayaran dividen tahun 0 dikurangi dengan pembayaran dividen tahun sebelumnya, dibagi dengan pembayaran dividen tahun sebelumnya. Dalam penelitian ini perubahan dividen dilakukan dengan cara pertama, karena data pembayaran dividen diambil dari data dividen per saham atau dividend per share. 


\section{Variabel Kontrol}

Penelitian ini bertujuan untuk menguji apakah perubahan dividen mengandung informasi baru tentang profitabilitas perusahaan pada masa yang akan datang. Oleh karena itu, dalam penelitian ini akan menggunakan beberapa variabel kontrol, yang diduga merupakan prediktor yang baik terhadap profitabilitas pada masa yang akan datang.

Dalam penelitian ini menggunakan tiga variabel kontrol, yaitu: (1) Return on Equity (ROE), (2) Book Value of Equity (BVE) dan (3) Market Value of Equity (P). $R O E$ merupakan prediktor yang kuat terhadap laba perusahaan yang akan datang (Freeman et al.,1982). Menurut penelitian mereka ROE berhubungan negatif dengan laba pada masa yang akan datang. Sedangkan $B V E$ juga merupakan predictor yang baik terhadap laba perusahaan pada masa yang akan datang, karena BE secara signifikan berhubungan dengan laba satu dan dua tahun ke depan (Nissim dan Ziv 2001). Market Value of Equity (P) juga merupakan predictor yang sering digunakan dalam menilai prospektif perusahaan pada masa yang akan datang.

Laba pada masa yang akan datang diduga dipengaruhi oleh laba tahun sebelumnya, yang terkait dengan kebijakan kenaikkan laba secara permanen oleh perusahaan (Benartzi et al., 1997). Untuk mengantisipasi hal tersebut maka dalam penelitian ini laba tahun peristiwa pembayaran dividen $\left(E_{0}\right)$ dan perubahan laba tahun peristiwa pembayaran dividen $(\triangle E 0)$ dan laba tidak normal tahun peristiwa pembayaran dividen $\left(A E_{0}\right)$ sebagai variabel kontrol.

\section{MODEL ANALISIS}

Secara umum model analisis dalam penelitian ini dapat dirumuskan sebagai berikut:

$$
Y t=\alpha 0+\alpha 1 X 0+\alpha n \Sigma \text { Var_kontrol0 }+e 1
$$

Keterangan:

Yt $\quad=$ Laba pada tahun $\boldsymbol{t}$ yang diukur dengan laba (earnings), perubahan laba (earnings change) dan laba tidak normal (abnormal earnings).

XO $=$ Perubahan dividen pada waktu $t 0$

$\Sigma$ Var_kontrolo $=$ Sejumlah variabel kontrol pada waktu $t 0$

Berdasarkan model analisis tersebut maka model regresi untuk masingmasing pengukuran laba beserta dengan variabel kontrolnya adalah sebagai berikut:

$$
\begin{aligned}
& \Delta E_{t}=\alpha_{0}+\alpha_{1} \Delta D I V_{0}+\alpha_{2} R O E_{0}+\alpha_{3} \Delta E_{0}+\alpha_{4} B V E_{0}+\alpha_{5} P_{0}+\varepsilon_{t} \ldots \ldots \\
& E_{t}=\alpha_{0}+\alpha_{1} \Delta D I V_{0}+\alpha_{2}{ }^{R O E_{0}}+\alpha_{3}{ }^{E_{0}}+\alpha_{4}^{B V E} 0+\alpha_{5} P_{0}+\varepsilon t \ldots \ldots \ldots . \\
& A E_{t}=\alpha_{0}+\alpha_{1} \Delta D I V_{0}+\alpha_{2} R O E_{0}+\alpha_{3} A E_{0}+\alpha_{4 B V E 0}+\alpha_{5} P_{0}+\varepsilon_{t}
\end{aligned}
$$


Dalam ketiga model regresi tersebut, model (4) merupakan model regresi dimana profitabilitas perusahaan pada masa yang akan datang diukur dengan menggunakan perubahan laba (earnings changes). Sedangkan model (5) merupakan model regresi dimana profitabilitas perusahaan diukur dengan menggunakan laba (earning). Pada model (6) pengukuran profitabilitas menggunakan laba tidak normal (abnormal earnings).

Hubungan antara perubahan dividen dengan profitabilitas tidak simetris untuk dividen yang meningkat dan dividen yang menurun. (DeAngelo dan DeAngelo 1990), Benartzi et al., 1997). Oleh karena itu, diduga terdapat perbedaan koefisien yang signifikan antara dividen meningkat dengan dividen menurun. Menurut penelitian yang pernah dilakukan, maka dalam penelitian ini akan dimasukkan variabel dummy, yaitu DPC (Dividend Positive Changes) dan DNC (Dividend Negative Changes). Dalam model regresi dengan variabel dummy, maka $D P C$ dan $D N C$ akan diberikan nilai 1 jika dividen naik atau turun dan akan diberikan nilai 0 kalau tetap. Sedangkan model regresi untuk masing-masing pengukuran adalah sebagai berikut:

$$
\begin{aligned}
& \Delta E t=\alpha 0+\alpha 1 \Delta D I V 0 \times 1 P C 0+\alpha 2 \Delta D I V 0 \times D N C 0+\alpha 3 R O E 0+\alpha 4 \Delta E 0+\alpha 5^{B V E} 0^{+} \\
& \alpha \sigma^{P} 0+\varepsilon_{t} \\
& E_{t}=\alpha_{0}+\alpha_{1} \Delta D I V_{0} \mathrm{x} D P C_{0}+\alpha_{2} \Delta D I V_{0} \mathrm{x} D N C_{0}+\alpha_{3} R O E_{0}+\alpha_{4} E_{0}+\alpha_{5} B V E_{0}+ \\
& \alpha 6 P 0+\varepsilon_{t}
\end{aligned}
$$

\section{HASIL EMPIRIS}

\section{Statistik Deskriptif}

Tabel 1 menunjukkan statistik deskriptif variabel penelitian untuk tahun 0,1 , 2, 3 dan 4. Nilai deskriptif masing-masing variabel dibuat secara bersama-sama dan tidak dipisahkan antara dividen naik dan dividen turun.

Tabel 1

Deskripsi Sampel Penelitian (Distribusi Observasi Firm-Year Perubahan Dividen dari 87 Perusahaan yang Mengumumkan Dividen dalam Periode 1997-2003)

\begin{tabular}{cccccccc}
\hline \multirow{2}{*}{ Tahun } & Naik & \% & Tetap & Dividen & Turun & \% & Total \\
\hline 1997 & 3 & 39,08 & 1 & 1,96 & 47 & 54,02 & 51 \\
1998 & 23 & 51,14 & 26 & 49,06 & 4 & 4,60 & 53 \\
1999 & 37 & 59,72 & 15 & 21,74 & 17 & 19,54 & 69 \\
2000 & 43 & 53,62 & 8 & 11,11 & 21 & 24,14 & 72 \\
2001 & 45 & 43,40 & 7 & 7,95 & 36 & 41,38 & 88 \\
2002 & 34 & 5,88 & 22 & 25,29 & 31 & 35,63 & 87 \\
Total & 185 & 44 & 79 & 18,8 & 156 & 37 & 420 \\
\hline Sumber: Data sekunder yang diolah & & & & &
\end{tabular}


Distribusi observasi firm-year perubahan dividen dari 87 perusahaan yang mengumumkan dividen dalam periode tahun 1997-2003.

Variabel dependen dalam penelitian ini adalah laba. Tiga pengukuran laba yang digunakan adalah: (1) tingkat laba (earnings); (2) perubahan laba (earnings changes) dan (3) Laba tidak normal (abnormal earnings) menurut Nissim dan Ziv (2001). Dalam penelitian ini data laba perusahaan diambil dari EPS (Earnings Per Share) masing-masing perusahaan yang membayar dividen dalam periode tahun 1998-2003. Variabel tingkat laba (earnings) diambil dari data EPS tahunan perusahaan, sedangkan variabel perubahan laba (earnings changes) dihitung dengan mengurangi EPS tahun berjalan dengan EPS tahun sebelumnya.

Variabel laba tidak normal (abnormal earning), merupakan selisih antara laba aktual perusahaan dengan rata-rata laba perusahaan yang membayar dividen tetap pada tahun berjalan pada industri yang sama. (Benartzi et al., 1997). Perhitungan abnormal earning menurut Benartzi (1997) melibatkan rata-rata perubahan laba dalam industri yang sama, karena diketahui bahwa profitabilitas perusahaan berkovari dengan profitabilitas industrinya, sedangkan perhitungan abnormal earning menurut Nissim dan Ziv (2001), hanya menghitung laba tidak normal berdasarkan kos dan tingkat modal ekuitas yang diinvestasikan. Laba tidak normal masing-masing perusahaan dihitung dengan rumus: $A E t=\Delta E t-{ }^{1} / j \Sigma \Delta E 0$ dimana $J=1 \ldots . ., j$ adalah semua perusahaan yang membayar dividen tetap pada waktu $t 0$ dalam industri yang sama. Berdasarkan data yang diperoleh dari perusahaan sampel, maka dapat disusun tabel statistik deskriptif masing-masing variabel sesuai dengan tujuan penelitian. Dalam Tabel 2 dapat dijelaskan masing-masing variabel adalah sebagai berikut: (1) $E_{t}$ adalah laba bersih pada tahun $t\left(0,1,2,3\right.$ dan 4), (2) $B V_{0}$ adalah nilai buku ekuitas pada tahun 0 , (3) $P 0$ adalah harga pasar ekuitas pada tahun 0 , (4) $\Delta E t$ adalah perubahan laba bersih dalam tahun $t(0,1,2,3,4)$ dibagi dengan nilai buku ekuitas, (5) $A E_{t}$ adalah abnormal earning dalam tahun $t(0,1,2,3,4)$ yang dihitung dari selisih laba aktual dengan rata-rata perubahan laba perusahaan pembayar dividen konstan pada tahun 0, (6) $\Delta$ Div 0 adalah perubahan dividen per lembar saham pada tahun 0. Dalam penelitian ini, tahun ke 0 adalah tahun 1999, merupakan tahun peristiwa. Sedangkan tahun pertama sampai tahun keempat masing-masing adalah tahun 2000 sampai tahun 2003.

Berdasarkan data dalam Tabel 2, terlihat bahwa deviasi standar masingmasing variabel cenderung besar. Earning tahun pertama $\left(\mathrm{E}_{1}\right)$ misalnya, mempunyai deviasi standar yang cukup besar $(71,054)$. Jumlah ini adalah sekitar 14 persen dari nilai maksimum $(485,683)$. Berdasarkan data dalam tabel tersebut mengindikasikan bahwa laba perusahaan yang menjadi sampel cenderung heterogen.

Berdasarkan data dalam Tabel 2, terlihat bahwa deviasi standar masingmasing variabel cenderung besar. Earning tahun pertama (E1) misalnya, mempunyai deviasi standar yang cukup besar $(71,054)$. Jumlah ini adalah sekitar 14 persen dari 
nilai maksimum $(485,683)$. Berdasarkan data dalam tabel tersebut mengindikasikan bahwa laba perusahaan yang menjadi sampel cenderung heterogen. Dilihat dari data perubahan earning juga mengindikasikan bahwa perubahan earning tahun pertama juga mempunyai standar deviasi yang paling besar $(69,098)$, hal ini mengindikasikan bahwa pada tahun 0 ke tahun pertama terjadi perubahan laba perusahaan yang cukup besar. Dari data abnormal earning standar deviasi terbesar terlihat pada tahun kedua $(48,683)$ hal ini juga mengindikasikan bahwa pada tahun kedua terdapat penurunan laba pada rata-rata industri, sehingga terdapat selisih yang besar pada nilai abnormal earning. Berdasarkan hasil korelasi antar variabel dalam matrik korelasi pearson, terlihat bahwa variabel utama $\Delta \mathrm{Div}_{0}$ berkorelasi positif signifikan dengan earning tahun ke empat (E4), perubahan earning tahun ke empat $(\Delta \mathrm{E} 4)$ dan perubahan earning tahun ke tiga $(\Delta \mathrm{E} 4)$. Di samping itu, variabel utama juga berkorelasi positif signifikan dengan abnormal earning tahun ke empat ( $\left.\mathrm{AE}_{4}\right)$. Berdasarkan tabel korelasi mengindikasikan bahwa pengumuman perubahan dividen mempunyai kandungan informasi terhadap profitabilitas masa yang akan datang khususnya untuk tiga dan empat tahun ke depan.

Tabel 2

Statistik Deskriptif Variabel Penelitian

\begin{tabular}{|c|c|c|c|c|c|}
\hline & $\mathbf{N}$ & Minimum & Maximum & Mean & Std. Deviation \\
\hline E 4 & 84 & 0,00 & 500,00 & 58,3571 & 126,4855 \\
\hline $\mathrm{E}_{3}$ & 83 & $-479,00$ & 4716,00 & 335,0530 & 834,2825 \\
\hline $\mathrm{E}_{2}$ & 85 & $-66,00$ & 36041,67 & 830,0749 & 3967,3337 \\
\hline E1 & 85 & $-135,00$ & 485683,92 & 11400,2332 & 71054,0892 \\
\hline $\mathrm{E}_{0}$ & 85 & $-307,00$ & 40946,41 & 946,7272 & 4477,3717 \\
\hline $\mathrm{BV}_{0}$ & 84 & $-0,20$ & 18,10 & 1,9143 & 2,9848 \\
\hline P0 & 84 & 0,00 & 34000,00 & 2618,2619 & 4809,3791 \\
\hline ROE0 & 84 & 0,00 & 57000,00 & 3768,5381 & 8116,5184 \\
\hline$\Delta \mathrm{Div}_{0}$ & 84 & $-1548,00$ & 2200,00 & 22,067 & 329,6482 \\
\hline$\Delta \mathrm{E}_{4}$ & 84 & $-449,00$ & 2365,00 & 55,5750 & 308,705 \\
\hline$\Delta \mathrm{E} 3$ & 85 & $-3930,30$ & 3543,70 & 90,7489 & 932,7411 \\
\hline$\Delta \mathrm{E}_{2}$ & 85 & $-3551,60$ & 10663,42 & 249,3202 & 1441,7189 \\
\hline$\Delta \mathrm{E}_{1}$ & 85 & $-3543,40$ & 460197,67 & 10816,9373 & 69098,1957 \\
\hline$\Delta \mathrm{E} 0$ & 85 & $-3542,90$ & 15315,16 & 360,0195 & 1837,0007 \\
\hline $\mathrm{AE}_{4}$ & 85 & $-3206,70$ & 4267,30 & 774,2964 & 861,6773 \\
\hline $\mathrm{AE}_{3}$ & 84 & $-2828,00$ & 4574,30 & 848,9429 & 883,9527 \\
\hline AE2 & 84 & $-2819,80$ & 446989,60 & 6190,7667 & 48683,3843 \\
\hline $\mathrm{AE}_{1}$ & 84 & $-2819,30$ & 4301,60 & 905,5821 & 829,7569 \\
\hline $\mathrm{AE}_{0}$ & 84 & $-31333,70$ & 2775,10 & $-792,4536$ & 4215,6690 \\
\hline
\end{tabular}

Sumber: Data sekunder yang diolah

\section{PEMBUKTIAN HIPOTESIS}

Berdasarkan hasil ringkasan regresi pada Tabel 3, baik pada panel A maupun panel B, profitabilitas perusahaan pada masa yang akan datang diukur dengan besarnya earning. Dalam Tabel 3 panel A terlihat bahwa untuk $\mathrm{t}=1$ koefisien perubahan dividen, $\left(\Delta \mathrm{Div}_{0}\right)\left(\boldsymbol{\alpha}_{1}\right)$ adalah positif sebesar 0,378 dan tidak signifikan. Hal yang sama juga terjadi pada tahun kedua samapi ketiga, dimana perubahan dividen tidak signifikan. Pada tahun keempat perubahan dividen signifikan dengan nilai 
koefisien sebesar positif 3,399. Hasil regresi ini mengindikasikan bahwa perubahan dividen mengandung informasi tambahan pada tahun ke empat. Sedangkan variabel kontrol yang signifikan adalah variabel earning dan variabel price tahun kedua. Sedangkan pada tahun ketiga variabel kontrol $R O E$, earning dan variabel price signifikan pada level 5 persen. Hasil ini mengindikasikan bahwa pengaruh perubahan dividen terhadap earning khususnya pada tahun ke dua dan ke tiga dipengaruhi oleh ROE, earning dan price.

Berdasarkan Tabel 3 panel $\mathrm{B}$, dimana dalam model dimasukkan variabel dummy, terlihat bahwa variabel dummy DPC dan DNC memiliki tingkat signifikansi yang berbeda. Pada tahun pertama perubahan dividen tidak signifikan, sedangkan pada tahun kedua sampai tahun keempat, perubahan dividen signifikan terhadap earning. Dalam tabel tersebut juga menunjukkan bahwa informasi kenaikan dividen memiliki pengaruh yang lebih kuat dibanding dengan informasi penurunan. Hal ini sesuai dengan temuan Nissim dan Ziv (2001), bahwa informasi kenaikan dividen merupakan berita baik baik investor, sedangkan informasi penurunan dividen merupakan berita buruk bagi investor.

Tabel 3

Ringkasan Statistik Regresi Earning satu sampai dengan empat tahun kedepan terhadap perubahan dividen $\left(\Delta D I V_{0}\right)$ dan Variabel Kontrol

A. $E_{t}=\alpha_{0}+\alpha_{1} \Delta D I V_{0}+\alpha_{2}^{R O E_{0}}+\alpha_{3} E_{0}+\alpha_{4}^{B V E}+\alpha_{5} P_{0}+\varepsilon_{t}$

\begin{tabular}{ccccccccc}
\hline $\mathbf{t}$ & $\boldsymbol{\alpha}_{\mathbf{0}}$ & $\boldsymbol{\alpha}_{\mathbf{1}}$ & $\boldsymbol{\alpha}_{\mathbf{2}}$ & $\boldsymbol{\alpha}_{\mathbf{3}}$ & $\boldsymbol{\alpha}_{\mathbf{4}}$ & $\boldsymbol{\alpha}_{\mathbf{5}}$ & $\mathbf{R}^{\mathbf{2}}$ & $\mathbf{N}$ \\
\hline 1 & 0,230 & 0,378 & 0,673 & 0,493 & 0,388 & 0,474 & 0,017 & 83 \\
& 1,209 & 0,886 & $-0,423$ & $-0,689$ & $-0,868$ & 0,720 & & \\
2 & 0,664 & 0,084 & 0,311 & 0,000 & 0,060 & 0,000 & 0,725 & 83 \\
& 0,436 & 1,750 & $-1,019$ & 3,702 & $-1,911$ & 3,927 & & \\
3 & 0,713 & 0,810 & 0,007 & 0,000 & 0,073 & 0,000 & 0,809 & 83 \\
& $-0,369$ & 0,241 & $-2,780$ & 4,946 & $-1,815$ & 5,016 & & \\
4 & 0,012 & 0,001 & 0,574 & 0,709 & 0,136 & 0,049 & 0,230 & 83 \\
& 2,558 & 3,399 & $-0,565$ & $-0,374$ & $-1,504$ & 2,003 & & \\
\hline
\end{tabular}

B. $E_{t}=\alpha_{0}+\alpha_{1} \Delta D I V_{0} \mathrm{X} D P C_{0}+\alpha_{2} \Delta D I V_{0} \mathrm{X} D N C_{0}+\alpha_{3} R O E_{0}+\alpha_{t} E_{0}+\alpha_{5} B V E_{0}+\alpha_{6} P_{0}+\varepsilon_{t}$

\begin{tabular}{cccccccccc}
\hline $\mathbf{t}$ & $\boldsymbol{\alpha}_{\mathbf{0}}$ & $\boldsymbol{\alpha}_{\mathbf{1}}$ & $\boldsymbol{\alpha}_{\mathbf{2}}$ & $\boldsymbol{\alpha}_{\mathbf{3}}$ & $\boldsymbol{\alpha}_{\mathbf{4}}$ & $\boldsymbol{\alpha}_{\mathbf{5}}$ & $\boldsymbol{\alpha 6}$ & $\mathbf{R}^{\mathbf{2}}$ & $\mathbf{N}$ \\
\hline 1 & 0,240 & 0,825 & 0,676 & 0,732 & 0,649 & 0,430 & 0,616 & 0,009 & 83 \\
& 1,185 & $-0,220$ & 0,419 & $-0,344$ & $-0,456$ & $-0,793$ & 0,503 & & 83 \\
2 & 0,719 & 0,001 & 0,026 & 0,167 & 0,000 & 0,016 & 0,000 & 0,773 & 82 \\
& 0,361 & $-3,324$ & 2,273 & $-1,394$ & 3,842 & $-2,458$ & 5,243 & & 83 \\
3 & 0,470 & 0,017 & 0,503 & 0,002 & 0,000 & 0,026 & 0,000 & 0,823 & \\
& $-0,726$ & $-2,447$ & 0,673 & $-3,253$ & 4,780 & $-2,278$ & 6,065 & & \\
4 & 0,398 & 0,002 & 0,034 & 0,901 & 0,007 & 0,481 & 0,118 & 0,280 & \\
& 0,850 & $-3,151$ & $-2,156$ & -1.125 & 2,793 & $-0,708$ & 1,579 & & \\
\hline
\end{tabular}

Berdasarkan Tabel 4 dimana profitabilitas diukur dengan perubahan earning, dapat dilihat bahwa perubahan dividen terhadap profitabilitas signifikan pada tahun ketiga dan keempat. Hal ini tidak konsisten dengan temuan Nissim dan 
Ziv (2001), tetapi hasil ini mengindikasikan bahwa informasi perubahan dividen tidak memiliki kandungan informasi pada tahun pertama dan kedua, tetapi justru pada tahun ketiga dan keempat. Tabel 4 panel A juga menunjukkan bahwa variabel kontrol berupa perubahan earning signifikan pada tahun kedua sampai tahun keempat, sedangkan variabel kontrol price signifikan pada tahun ke empat saja.

Pada panel B terlihat bahwa $D P C$ dan $D N C$ semua signifikan pada tahun ke empat, dengan koefisien $D P C$ lebih besar. Hal ini menunjukkan bahwa informasi kenaikan dividen lebih kuat mempengaruhi profitabilitas dibandingkan dengan informasi penurunan dividen. Hal ini konsisten dengan temuan Nissim dan Ziv (2001).

Dalam Tabel 5 profitabilitas ditunjukkan dengan abnormal earning. Hasil regresi pada panel A menunjukkan bahwa informasi perubahan dividen tidak ada yang signifikan, pada tahun pertama sampai dengan tahun keempat. Dalam model ini dapat dilihat juga bahwa variabel kontrol book value dan price signifikan pada tahun pertama dan tahun ketiga dan ke empat. Hal ini menunjukkan bahwa informasi perubahan dividen tidak memiliki kandungan informasi profitabilitas perusahaan yang tercermin dalam abnormal earning.

Tabel 4

Ringkasan Statistik Regresi Perubahan Earning satu sampai dengan empat tahun kedepan terhadap Perubahan Dividend dan Variabel Kontrol

A. $\Delta E_{t}=\alpha_{0}+\alpha_{1} \Delta D I V_{0}+\alpha_{2} R O E_{0}+\alpha_{3} \Delta E_{0}+\alpha_{4} B V E_{0}+\alpha_{5} P_{0}+\varepsilon_{t}$

\begin{tabular}{ccccccccc}
\hline $\mathbf{t}$ & $\boldsymbol{\alpha}_{\mathbf{0}}$ & $\boldsymbol{\alpha}_{\mathbf{1}}$ & $\boldsymbol{\alpha}_{\mathbf{2}}$ & $\boldsymbol{\alpha}_{\mathbf{3}}$ & $\boldsymbol{\alpha}_{\mathbf{4}}$ & $\boldsymbol{\alpha}_{\mathbf{5}}$ & $\mathbf{R}^{\mathbf{2}}$ & $\mathbf{N}$ \\
\hline 1 & 0,316 & 0,559 & 0,860 & 0,197 & 0,593 & 0,896 & 0,011 & 83 \\
& 1,010 & 0,587 & $-0,177$ & 0,027 & $-0,537$ & 0,13 & & \\
2 & 0,359 & 0,393 & 0,410 & 0,000 & 0,824 & 0,667 & 0,674 & 83 \\
& $-0,923$ & $-0,859$ & 0,828 & 9,281 & $-0,223$ & 0,432 & & \\
3 & 0,065 & 0,004 & 0,492 & 0,000 & 0,790 & 0,389 & 0,742 & 83 \\
& $-1,870$ & $-3,007$ & $-0,691$ & 11,278 & 0,267 & 0,866 & & \\
4 & 0,008 & 0,002 & 0,236 & 0,000 & 0,916 & 0,000 & 0,753 & 83 \\
& $-2,740$ & $-3,206$ & $-1,193$ & 4,394 & $-0,106$ & 6,569 & & \\
\hline
\end{tabular}

B. $\Delta E_{t}=\alpha_{0}+\alpha_{1} \Delta D I V_{0 \times} D P C_{0}+\alpha_{2} \Delta D I V_{0 \times} D N C_{0}+\alpha_{3} R O E_{0}+\alpha_{4} \Delta E_{0}+\alpha_{5} B V E_{0}+\alpha_{6} P_{0}+\varepsilon_{t}$

\begin{tabular}{cccccccccc}
\hline $\mathbf{t}$ & $\boldsymbol{\alpha}_{\mathbf{0}}$ & $\boldsymbol{\alpha}_{\mathbf{1}}$ & $\boldsymbol{\alpha}_{\mathbf{2}}$ & $\boldsymbol{\alpha}_{\mathbf{3}}$ & $\boldsymbol{\alpha}_{\mathbf{4}}$ & $\boldsymbol{\alpha}_{\mathbf{5}}$ & $\boldsymbol{\alpha 6}$ & $\mathbf{R}^{\mathbf{2}}$ & $\mathbf{N}$ \\
\hline 1 & 0,308 & 0,796 & 0,906 & 0,845 & 0,832 & 0,572 & 0,832 & 0,007 & 83 \\
& 1,026 & $-0,260$ & 0,118 & $-0,197$ & 0,213 & $-0,568$ & 0,213 & & \\
2 & 0,118 & 0,024 & 0,865 & 0,644 & 0,000 & 0,648 & 0,048 & 0,692 & 83 \\
& $-1,581$ & $-2,308$ & 0,171 & 0,464 & 8,997 & $-0,458$ & 2,01 & & \\
3 & 0,004 & 0,091 & 0,052 & 0,280 & 0,000 & 0,766 & 0,042 & 0,739 & 83 \\
& $-3,010$ & $-1,710$ & $-1,974$ & $-1,089$ & 11,107 & 0,299 & 2,068 & & \\
4 & 0,022 & 0,000 & 0,000 & 0,700 & 0,043 & 0,151 & 0,250 & 0,969 & 83 \\
& $-2,332$ & 22,844 & 6,273 & 0,387 & 2,061 & 1,449 & $-1,158$ & & \\
\hline
\end{tabular}

Sedangkan pengaruh perubahan dividen positif dan negatif terhadap abnormal earning, pada Tabel 5 panel B menunjukkan bahwa informasi penurunan dividen 
pada tahun pertama dan tahun ketiga signifikan pada level 5 persen. Sedangkan informasi kenaikan dividen tidak ada yang signifikan. Hal ini tidak konsisten dengan temuan Nissim dan Ziv (2001). Temuan ini mengindikasikan bahwa informasi penurunan dividen memiliki kandungan informasi atau korelasi dengan abnormal earning untuk satu tahun ke depan, sementara informasi kenaikan dividen tidak demikian.

Tabel 5

Ringkasan Statistik Regresi Abnormal Earning satu sampai dengan empat tahun kedepan terhadap Perubahan Dividend dan Variabel Kontrol

A. $A E_{t}=\alpha_{0}+\alpha_{1} \Delta D_{I V}+\alpha_{2} R_{O E}+\alpha_{3} A E_{0}+\alpha_{4} B_{V E}+\alpha_{5} P_{0}+\varepsilon t$

\begin{tabular}{ccccccccc}
\hline $\mathbf{t}$ & $\boldsymbol{\alpha}_{\mathbf{0}}$ & $\boldsymbol{\alpha}_{\mathbf{1}}$ & $\boldsymbol{\alpha}_{\mathbf{2}}$ & $\boldsymbol{\alpha}_{\mathbf{3}}$ & $\boldsymbol{\alpha}_{\mathbf{4}}$ & $\boldsymbol{\alpha}_{\mathbf{5}}$ & $\mathbf{R}^{\mathbf{2}}$ & $\mathbf{N}$ \\
\hline 1 & 0,000 & 0,838 & 0,718 & 0,546 & 0,013 & 0,000 & 0,346 & 83 \\
& 7,634 & 0,206 & $-0,363$ & $-0,607$ & $-0,529$ & 4,244 & & \\
2 & 0,242 & 0,524 & 0,835 & 0,709 & 0,517 & 0,805 & 0,012 & 83 \\
& 1,180 & 0,639 & $-0,209$ & 0,375 & $-0,651$ & 0,247 & & \\
3 & 0,000 & 0,766 & 0,810 & 0,543 & 0,039 & 0,001 & 0,317 & 83 \\
& 6,563 & $-0,299$ & 0,242 & 0,610 & $-2,095$ & 3,426 & & \\
4 & 0,000 & 0,139 & 0,422 & 0,342 & 0,053 & 0,000 & 0,329 & 83 \\
& 6,389 & $-1,495$ & $-0,807$ & 0,956 & 1,967 & 3,976 & & \\
\hline
\end{tabular}

B. $A E_{t}=\alpha_{0}+\alpha_{1} \triangle D I V 0 \times D P C 0+\alpha_{2} \triangle D I V 0 \times D N C 0+\alpha_{3} R_{0} E_{0}+\alpha_{4} A E_{0}+\alpha_{5} B V E 0+\alpha_{6} P_{0}+\varepsilon_{t}$

\begin{tabular}{cccccccccc}
\hline $\mathbf{t}$ & $\boldsymbol{\alpha}_{\mathbf{0}}$ & $\boldsymbol{\alpha}_{\mathbf{1}}$ & $\boldsymbol{\alpha}_{\mathbf{2}}$ & $\boldsymbol{\alpha}_{\mathbf{3}}$ & $\boldsymbol{\alpha}_{\mathbf{4}}$ & $\boldsymbol{\alpha}_{\mathbf{5}}$ & $\boldsymbol{\alpha 6}$ & $\mathbf{R}^{\mathbf{2}}$ & $\mathbf{N}$ \\
\hline 1 & 0,000 & 0,056 & 0,001 & 0,900 & 0,55 & 0,024 & 0,213 & 0,479 & 83 \\
& 9,285 & 1,943 & 3,408 & 0,126 & $-0,599$ & $-2,308$ & 1,255 & & \\
2 & 0,228 & 0,815 & 0,819 & 0,831 & 0,757 & 0,501 & 0,799 & 0,008 & 83 \\
& 1,215 & $-0,235$ & 0,230 & $-0,214$ & 0,310 & $-0,676$ & 0,256 & & \\
3 & 0,000 & 0,746 & 0,010 & 0,740 & 0,405 & 0,037 & 0,021 & 0,375 & 83 \\
& 6,982 & $-0,326$ & 2,655 & 0,333 & 0,837 & $-2,120$ & 2,366 & & \\
4 & 0,000 & 0,724 & 0,144 & 0,492 & 0,224 & 0,074 & 0,021 & 0,333 & 83 \\
& 6,362 & 0,355 & 1,478 & $-0,691$ & 1,227 & $-1,810$ & 2,354 & & \\
\hline
\end{tabular}

\section{SIMPULAN}

Penelitian ini menguji kandungan informasi perubahan dividen tentang profitabilitas perusahaan di masa yang akan datang. Penelitian ini juga menguji arah hubungan perubahan dividen dengan profitabilitas di masa yang akan datang. Penelitian ini meregres laba yang diukur dengan tiga pengukuran yaitu: (1) tingkat laba (earning); (2) perubahan laba (earning changes) dan (3) laba tidak normal (abnormal earning), terhadap perubahan dividen dengan beberapa variabel kontrol. Dengan menggunakan data panel informasi perubahan dividen sebanyak 420 observasi dari 87 perusahaan dari tahun 1997 sampai tahun 2003, penelitian ini menemukan bukti empiris bahwa perubahan dividen tidak memiliki tambahan kandungan informasi untuk tingkat laba, untuk satu tahun ke depan, memiliki tambahan kandungan informasi untuk empat tahun ke depan. Hasil ini tidak sepenuhnya mendukung hasil temuan Nissim dan Ziv (2001). Sedangkan pada 
pengukuran profitabilitas masa yang akan datang, dengan perubahan laba, perubahan dividen memiliki tambahan kandungan informasi untuk tiga dan empat tahun ke depan. Perubahan dividen tidak memiliki tambahan kandungan informasi untuk satu sampai empat tahun ke depan, untuk profitabilitas yang diukur dengan laba tidak normal. Temuan ini mendukung hipotesis pertama dan kedua tetapi hanya untuk tingkat laba dan perubahan laba saja.

Hasil penelitian ini juga menunjukkan bahwa informasi kenaikan dividen memiliki tambahan kandungan informasi yang berbeda dengan informasi penurunan dividen. Hal ini terjadi untuk pengukuran profitabilitas dengan laba, perubahan laba dan laba tidak normal. Hasil penelitian tidak sejalan dengan temuan Nissim dan Ziv (2001), dimana justru perubahan dividen meningkat memiliki korelasi dengan tingkat laba untuk dua sampai empat tahun ke depan. Sedangkan untuk perubahan laba informasi kenaikan dividen memilki korelasi yang lebih kuat dibandingkan dengan informasi penurunan dividen pada empat tahun ke depan. Adanya bukti empiris tambahan kandungan informasi kenaikan dividen tentang profitabilitas perusahaan pada masa yang akan datang memberikan sinyal bahwa informasi kenaikan dividen mengindikasikan kepercayaan manajemen tentang kaitan antara dividen meningkat dengan kinerja laba yang lebih baik secara permanen (Lintner 1956). Tetapi kesimpulan tersebut masih memerlukan pengujian lebih lanjut, apakah benar kenaikan pembayaran dividen menjadi sinyal positif bagi manajemen dan investor.

Temuan ini paling tidak memberikan indikasi bagi investor bahwa ketika perusahaan mengumumkan dividen menurun, maka kemungkinan besar akan tidak akan diikuti dengan penurunan laba pada satu sampai tiga tahun ke depan. Temuan ini juga dapat dijadikan pertimbangan bagi perusahaan dalam menetapkan kebijakan dividen dalam jangka panjang, karena informasi perubahan dividen mengandung informasi mengenai prospek perusahaan pada masa yang akan datang.

Penelitian ini memiliki beberapa keterbatasan yang patut diungkapkan agar dapat diperbaiki di masa yang akan datang. Keterbatasan tersebut antara lain adalah: (1) belum mengontrol secara langsung sampel yang kemungkinan melakukan stock split dan atau right issue yang kemungkinan dapat mempengaruhi profitabilitas perusahaan di masa yang datang; (2) Penelitian ini hanya menguji data perusahaan selama empat tahun dan hanya 87 perusahaan; (3) penelitian ini tidak memasukkan perusahaan asuransi dan perusahaan jasa keuangan.

\section{DAFTAR PUSTAKA}

Aharony, J., dan I. Swary. 1980. Quarterly dividend and earnings announcements and stockholders returns: An empirical analysis. Journal of Finance. Vol.35: $1-12$.

Asquith, P., dan D. W. Mullins. 1983. The impact of initiating dividend payments 
on shareholders wealth. Journal of Business. Vol.56: 77-96.

Bhattacharya, S. 1979. Imperfect information dividend policy, and the bird in the hand fallacy. Bell Journal Of Economic. Vol.10: 259-270.

Benartzi, S., R. Michaely, dan R. Thaler. 1997. Do changes in dividends signal the future or the past? Journal of Finance. Vol.52: 1007-1034.

Brigham, E. F., dan J. F. Houston . 2001. Fundamental of Financial Management. Ninth Edition. Harcourt College Publishers.

Brigham, E. F., dan P. R. Daves. 2002. Intermediate Financial Management. Seventh Edition. South Western.

Brittain, J. A. 1966. Corporate Dividend Policy. Washington D.C: Brookings Institute.

Bukit, R. B., dan J. Hartono. 2000. Analisis korelasi pokok IOS dengan realisasi pertumbuhan, kebijakan pendanaan dan dividen. Makalah Simposium Nasional Akuntansi III: 851-877.

DeAngelo, H., L. DeAngelo, dan D. J. Skiner. 1996. Reversal of fortune: Dividend signaling and the disappearance of sustained earnings growth. Journal of Financial Economics. Vol.40: 341-371.

Dennis dan Sarin. 1994. The information content of dividend changes: Cash flow signalling, over investment, and dividend clintless. Journal of Financial and Quantitative Analysis. (Desember): 567-587.

Fama, E. F., dan R. F. Kenneth. 2000. Forecasting profitability and earnings. Journal of Business. Vol.73: 161-175.

Fama, E. F., dan H. Babiak. 1968. Dividend policy of individual firms: An empirical analysis. Journal of the American Statistical Association. Vol.63: 1132-1161.

Freeman, R. N., J. A. Ohlson, dan S. H. Penman. 1982. Book rate of return and prediction of earnings changes: An empirical investigation. Journal of Accounting Research. Vol.20: 639-653.

Ghozali, I. 2001. Aplikasi Analisis Multivariate Dengan Program SPSS. Edisi 1. Badan Penerbit Universitas Diponegoro.

Healy, P. M., dan K. G. Palepu. 1988. Earnings information convened by dividend initiations and omissions. Journal of Financial Economics. Vol.21: 149-175.

1997-2003. Indonesian Capital Market Directory. EFCIN. Jakarta: BEJ.

Kalay, A., dan U. Loewenstein. 1985. Predictable events and excess returns: The case of dividend announcements. Journal of Financial Economics. Vol.14: 423-449.

Lang, L. H. P., dan Lintzerberger. 1989. Dividend announcements: Cash flow 
signalling vs free cash flow hipothesis? Journal of Financial Economics. (September): 181-191.

Michaely, R., R. H. Thaler, dan K. Womack. 1995. Price reactions to dividend initiations and omissions: Overreaction of drift? Journal of Finance. Vol.50: 573-608.

Miller, M., dan F. Modigliani. 1961. Dividend policy, growth and the valuation of shares. Journal of Business. Vol.34: 411-433.

Miller, M., dan R. Kevin. 1982. Dividend policy under asymetric information draft. November.

Nissim D., dan A. Ziv. 2001. Dividend changes and future profitability. Journal of Finance. Vol.8: 2111-2133.

Petit, R. R. 1972. Dividend announcements, security performance, and capital market efficiency. Journal of Finance. Vol.27: 993-1007.

Ross, S. S. 1977. The determination of financial structure: the incentive signaling approach. Bell Journal of Economics. Spring. Vol.8: 23-40.

Sartono, A. 2001. Manajemen Keuangan Teori dan Aplikasi. Edisi 4. BPFE: Yogyakarta.

Tandelilin E. 2001. Analisis Investasi dan Manajemen Portofolio. Edisi pertama, BPFE: Yogyakarta.

Wansley, J., C. Sirman, J. Shilling, dan Y. J. Lee. 1991. The information content of dividend. Journal of Business. Vol.46: 37-49.

Watts, R. 1973. The information content of dividends. Journal of Business. Vol.46 (April): 191-211. 